\title{
Shorebird predation may explain the origin of Holocene beds of stout razor clams in life position
}

\author{
Oscar Iribarne*, Juan Valero, Mariano M. Martinez, Luis Lucifora, Silvina Bachmann
}

Departamento de Biología (FCEyN), Universidad Nacional de Mar del Plata, CC 573 Correo Central (7600), Mar del Plata, Argentina

\begin{abstract}
Several hypotheses have been proposed to explain the origin of death assemblages of stout razor clams Tagelus plebejus buried in life position found in Holocene sediments in coastal Argentina and Uruguay: (1) a rapid decrease of sea level, (2) obstruction of the mouth of a coastal lagoon and episodic deposition of fluvial sediments in the mouth of a creek, and (3) a 'taphonomic feedback' process. Hypothesis 1 has been discarded, Hypothesis 2 only has a local explanation, while based on current information Hypothesis 3 is unlikely. A bird predation hypothesis is proposed here on the basis of a study of an extant population. The density of an extant population at the Mar Chiquita coastal lagoon. Argentina $\left(37^{\circ} 46^{\prime} \mathrm{S}, 57^{\circ} 27^{\prime} \mathrm{W}\right)$, is higher in the lower intertidal (un to 200 clams $\mathrm{m}^{-2}$ ) and decreases towards the upper intertidal, and clam size is correlated with burial depth. However, live individuals there coexist with large densities (up to 1500 clams $\mathrm{m}^{-2}$ ) of dead clams in life position, with densities peaking at the middle-upper intertidal. These shells showed no size - depth of burial correlation. Stout razor clams in fossil deposits (1500 yr BP) also showed large densities of shells in life position $\left(528\right.$ clams $\mathrm{m}^{-2}, \mathrm{SD}=$ $16, n=20$ ) with no clam size - burial depth relationship. Predation by the American oystercatcher Haematopus palliatus is an important cause of mortality year-round, taking 28 clam $h^{-1}$ during $3: 43 \mathrm{~h} \mathrm{~d}^{-1}$ Half of the successful attacks left shells in life position buried in the sediment. A computer simulation based on this information showed that predation by 1 oystercatcher produces 9.2 life-position shells $\mathrm{m}^{-2} \mathrm{yr}^{-1}(\mathrm{SD}=3.7$ lifeposition shells $\left.\mathrm{m}^{-2} \mathrm{yr}^{-1}, \mathrm{n}=10000\right)$. Thus, $89.5 \mathrm{yr}(95 \% \mathrm{Cl}=$ $50-422$ yr) are required to generate a mean shell density sim-

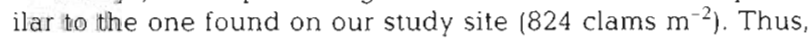
predation by oystercatchers generates a pattern similar to fossil assemblages and is the most likely explanation for the Holocene shell assemblages of the stout razor clams.
\end{abstract}

KEY WORDS: Intertidal - Predation Paleoecology - Stout razor clams Oystercatchers

Paleoecology studies the interactions between organisms and their environment in the geological past (Dodd \& Stanton 1990) using evidence from fossils and

·E-mail: osiriba@map.edu.ar burial environments. In contrast with ecologists, a paleoecologist often makes inferences about the environment using paleontologic and geologic evidence (Dodd \& Stanton 1990). As a result, paleocommunity structures are often thought to be shaped by physical processes instead of biological interactions. However, biases in the interpretation of past environmental processes may result if biological processes, although important, were not detected or considered.

Holocene estuarine sediments found along coastal Argentina and Uruguay (Fig. 1) are characterized by extensive death assemblages of the articulated stout razor clam Tagelus plebeius buried in life position. These assmblages are located in well-defined horizons (up to $40 \mathrm{~cm}$ thick) that span from 7000 to $1500 \mathrm{yr} \mathrm{BP}\left({ }^{14} \mathrm{C}\right.$ dates; Schnack et al. 1982, Aliotta \& Farinati 1990, Farinati et al. 1992, Gonzalez et al. 1983). Several hypotheses have been proposed to explain their origin. First, a rapid descent of sea level (Schnack et al. 1982) was proposed, but given the lack of evidence of rapid changes in sea level during the Holocene this hypothesis has lost its support (Isla \& Rivero D'Andrea 1993). Obstruction of the mouth of the Mar Chiquita coastal lagoon (Schnack et al. 1982, see Fig 1) and episodic deposition of fluvial sediments at the mouth of the Naposta Grande creek (Bahía Blanca; Farinati et al, 1992, see Fig. 1) have also been proposed to explain the stout razor clam shell deposits. Although both events may have occurred, they fail to explain the presence of death assemblages over the whole distribution range. A taphonomic-feedback process (sensu Kidwell \& Jablonski 1983) has also been proposed (Isla \& Rivero D'Andrea 1993) suggesting that increases in shell deposition over time may have generated a hard substratum that would make it impossible for later clams to grow and survive. This explanation is also unlikely because extant razor clam populations are living in areas which are heavily filled by shell deposits (authors' pers. obs.). 


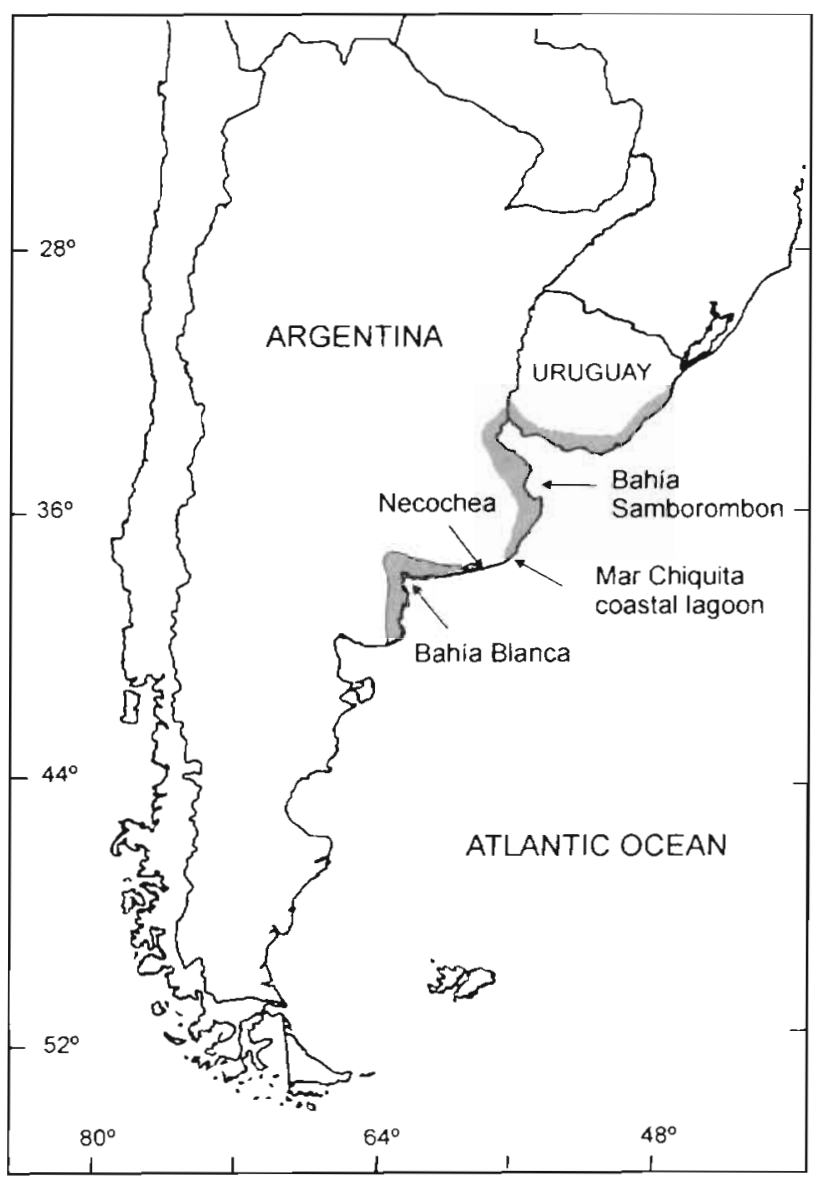

Fig. 1. Location of fossil shell assemblages (shaded area) in SW Atlantic coastal areas. The study was performed in Mar Chiquita coastal lagoon

Radiocarbon dates of fossil shells provide evidence of time-averaging. Three stout razor clam shells dated from the same level of the Quequen Grande River (Necochea, Argentina) fossil assemblage showed ages of $6440( \pm 100), 6850( \pm 110)$, and $6360( \pm 100)$ yr BP (Golfieri 1996), which indicates an approximate mean time-averaging of $490 \mathrm{yr}$. Dating of stout razor clams from the Naposta Grande creek showed ages of 3850 $( \pm 100), 3560( \pm 100)$ (Gonzalez et al. 1983) and $3373 \mathrm{yr}$ BP (Farinati 1985), which is approximately 477 yr of time-averaging. Given that small sample size makes the discovery of the youngest and the oldest shells very unlikely, the actual time-averaged value is likely to be much greater (Flessa \& Kowalewski 1994). This evidence suggests that instead of catastrophic events occurring, the shells have accumulated over time.

Extant populations of the stout razor clam are currently distributed on the west Atlantic coast estuarine environments from North Carolina $\left(34^{\circ} \mathrm{N}\right.$, USA; Holland \& Dean $1977 \mathrm{a}, \mathrm{b})$ to the San Matias Gulf $\left(41^{\circ} \mathrm{S}\right.$, Argentina; Carcelles 1944, Coscaron 1959). They are found from $30 \mathrm{~cm}$ below mean low water (MLW) to $90 \mathrm{~cm}$ above MLW and densities range from 200 clams $\mathrm{m}^{-2}$ just above MLW to $<5$ clams $\mathrm{m}^{-2}$ at 50 to $90 \mathrm{~cm}$ above MLW (Holland \& Dean 1977a, b). Large densities are found in the SW Atlantic estuaries, and provide good insight into the processes that may have generated the fossil assemblages. Although biological and ecological information on this species is scarce regarding the southern part of their distribution, it is known that predation by the American oystercatcher Haematopus palliatus is an important source of mortality along the Argentinean estuaries (Bachmann \& Martinez 1995). During the predation procedure, some of the razor clams are entirely pulled out from the sediment whilst in other cases only the soft parts are removed and both valves are left buried in the sediment, standing in their life position (authors' pers. obs.). If this process continues long enough, oystercatchers may be able to generate an accumulation of shells standing in life position that is similar to the one found in the Holocene deposits. If so, horizons of articulated fossil stout razor clam may have been generated through time-averaging, due to predation, instead of catastrophic events. In this work we evaluate this hypothesis by studying an extant stout razor clam bed located in a SW Atlantic coastal lagoon. With this information we develop a simple computer model to estimate the time necessary to generate a shell assemblage similar to the one found in the study area.

Material and methods. Study site and sampling procedure: The study was performed at the Mar Chiquita lagoon $\left(37^{\circ} 46^{\prime} \mathrm{S}, 57^{\circ} 27^{\prime} \mathrm{W}\right)$, an active coastal lagoon in Argentina (Schnack et al. 1982). It is a brackish water lagoon measuring approximately $46 \mathrm{~km}^{2}$, and it is affected by low amplitude $(\leq 1.5 \mathrm{~m})$ tides and characterized by mudflats and a large surrounding area of cordgrass Spartina densiflora (Fasano et al. 1982). The lagoon originated during the regressive phase that followed a transgressive maximum (about 5000 yr BP) which resulted in a sea level 2 to $2.5 \mathrm{~m}$ over the present level (Fasano et al. 1982). Well-defined horizons of Tagelus plebeius fossil shells standing in life position originated during this regressive phase and can be found in sediments surrounding the lagoon (Schnack et al. 1982, Gonzalez et al. 1983). Observations and sampling on an extant population were carried out from winter 1995 to summer 1996 in an area near the mouth of the lagoon.

Sampling of the stout razor clams was performed at MLW at different sites to locate extant razor clams and evaluate their density. At each site 10 replicates of $0.25 \mathrm{~m}^{2}$ area were randomly located, and because previous samples showed a good correlation $(\mathrm{r}=0.87, \mathrm{n}=$ $70, p<0.05$ ) between the number of siphon holes on the surface and the number of clams, clam density was 
estimated by counting pairs of siphon holes. Samples $\left(0.25 \mathrm{~m}^{2}\right.$ area, $0.8 \mathrm{~m}$ depth, $\left.\mathrm{n}=10\right)$ were also taken from fossil deposits located along the lagoon coastline at sites previously dated $\left({ }^{14} \mathrm{C}\right.$ date: 1500 yr BP; Schnack et al. 1982).

If dead shell assemblages are the product of predation by the oystercatcher, we expect to find them restricted to the intertidal where oystercatchers are able to reach them. To evaluate this hypothesis we took samples $10.25 \mathrm{~m}^{2}$ area by $80 \mathrm{~cm}$ depth, $\mathrm{n}=18$, homogeneously covering the intertidal and upper subtidal.) from the extant population at several tidal levels (slope of $0.6 \%$, intertidal width $=98 \mathrm{~m}$ ) following a line perpendicular to the shoreline. In each sample we counted live razor clams and articulated empty shells standing in life position with the flexible ligament still attached. The lengths of live individuals and shells in life position were measured and their burial depth was recorded. Then shells in life position were sorted into those without flexible ligament and those with the ligament still flexible. This classification identified the proportion of recently dead clams (those with a stillflexible ligament). To evaluate the possibility of sizeselection by predators, the null hypothesis of no difference between the size frequency distribution of the buried extant razor clams and those found dead on the surface were contrasted with the Kolmogorov-Smirnov test (Zar 1984).

Evaluadion of predation by the American oystercatcher on Tagelus plebeius: Oystercatcher censuses were performed every 2 wk from March 1993 to August 1994 at 13 intertidal sites of more than $2000 \mathrm{~m}^{2}$ each. To estimate bird density, the areal extent was calculated from the difference between the mean low water and the mean high water level obtained from aerial photographs. Individual behavior was studied by daily observations (minimum time of $6 \mathrm{~h}$ ) which included a complete tidal period. During each daily sample, oystercatchers were counted, and scan sampling (Altman 1974) was used to record the activity (resting or feeding) and prey type (clam and/or crab) in the different areas. Feeding activity was registered by focal sampling (Altman 1974), which consisted of 15 min of continuous observation of an individual's behavior. A total of $30 \mathrm{~h}$ of focal sampling was recorded by following 144 oystercatchers during feeding. Focal sampling was done over a full year.

Daily observations of oystercatchers were also carried out for $1 \mathrm{wk}$ (15 to 22 September 1996) in a previously demarcated area ( $200 \mathrm{~m}$ coastline by $50 \mathrm{~m}$, at low tide). The number of razor clams eaten was counted, discriminating between those that were taken as a whole and those for which only the soft part was extracted, leaving the shells buried in the sediment. With this information we evaluated the percentage of razor clams eaten by the American oystercatcher and left as shells in life position buried in the sediment.

Simulation of predation rate: Using the above observations we developed a computer iterative resampling procedure to estimate the amount of shells standing in life position (SSLP) that oystercatchers may generate per year. The following equation describes the model:

\section{$\operatorname{SSLP}(\operatorname{SD}(\operatorname{SSLP}))=\operatorname{CLS}(\mathrm{SD}(\mathrm{CLS})) \cdot \operatorname{TOPD}(\mathrm{SD}(\mathrm{TOPD})) \cdot$ DPYP(SD(DPYP $){ }^{*}$ DOC (SD(DOC))}

where CLS = number of clams left in the sediment by oystercatchers per hour, TOPD $=$ number of hours that oystercatchers prey per day, DPYP = number of days per year that oystercatchers preyed on clams at this site, $\mathrm{DOC}=$ density of birds at the studied area, $\mathrm{SD}=$ standard deviation of the estimated value, and an asterisk denotes multiplication. The equation assumes linear multiplicative responses of predation to prey density. A resampling technique (Manly 1992) was used to randomly select values from a normal distribution of each variable with mean and variance fixed at their estimated values. The median and a confidence level of $95 \%$ for the estimates were obtained from the distribution that resulted from 10000 iterative replications, which allowed confidence limits of $10 \%$ around the mean estimation to be achieved.

To compare the amount of clams left in life position due to bird predation with abundances of shells buried, we estimated the amount of shells in life position found in the demarcated area. Given that density changes with height in the intertidal, a stratified random sampling was carried out to evaluate the overall. shell density. The intertidal was divided into 3 strata of equal area $(0$ to $30 \mathrm{~cm}$ above MLW, 31 to $60 \mathrm{~cm}$ above MLW, 61 to 90 above MLW; $666.6 \mathrm{~m}^{2}$ each), and 10 samples were allocated to each area. The mean shell density and $95 \%$ confidence intervals were estimated, based on a stratified equal sampling ( $\mathrm{n}=10$ samples per strata) design (Thompson 1992). Samples were $0.25 \mathrm{~m}^{2}$ area by $80 \mathrm{~cm}$ depth where we counted articulated empty shells standing in life position.

Results. Stout razor clam density and distribution: Razor clams are mainly restricted to the mouth of the Mar Chiquita lagoon. The density of clams was higher in the intermediate and lower intertidal (up to 200 clams $\mathrm{m}^{-2}$ ) and decreased toward the upper intertidal (Fig. 2). Shell size was significantly correlated with burial depth $\left(r^{2}=0.8, n=43, p<0.05\right)$. Coexisting with live individuals, we found large densities of dead clams in life position, most with their ligament still attached and flexible. The density of these shells reached up to 1500 clams $\mathrm{m}^{-2}$, greatly exceeding the density of live individuals, with a maximum value in the middle-upper intertidal (Fig. 2). Shells standing in 


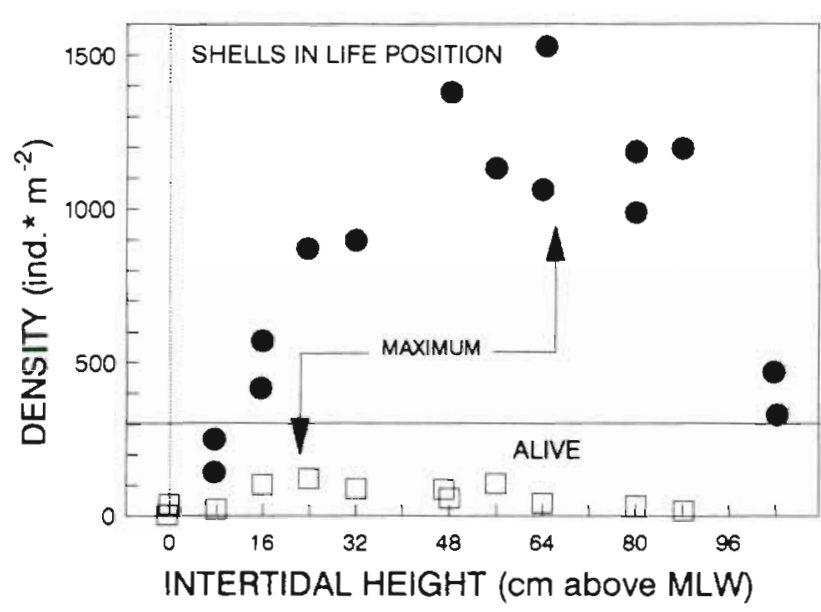

Fig. 2. Relationship between Tagelus plebeius shells in life position ( ) found buried in the substratum and live individuals ( $\square$ ) versus intertidal height measured in cm above mean low water (MLW). Arrows indicate the maximum mean values found during our study. The solid line indicates the maximum density found for live clams

life position obtained from the mid-intertidal showed no correlation $\left(\mathrm{r}^{2}=0.02, \mathrm{n}=50, \mathrm{p}>0.05\right)$ with burial depth.

Samples taken from fossil deposits showed a density of shells in life position of 528 clams $m^{-2}(\mathrm{SD}=16, \mathrm{n}=$ 20), with no relationship between burial depth and clam size $\left(\mathrm{r}^{2}=0.04, \mathrm{n}=73, \mathrm{p}>0.05\right)$.

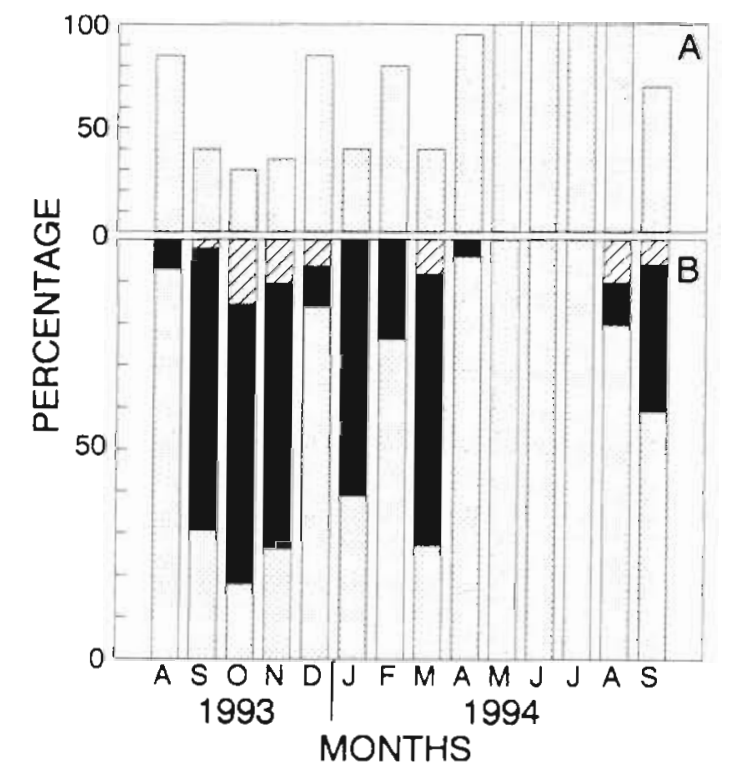

Fig. 3. (A) Percentage of feeding time allocated to feeding on stout razor clams Tagelus plebeius by American oystercatchers Haematopus palliatus and (B) percentage of oystercatchers feeding on different prey species (dotted bars: stout razor clams; black bars: crabs; hatched bars: both items) during the period 1993-1994 at the Mar Chiquita coastal lagoon
Evaluation of predation by American oystercatchers on stout razor clams: The only stout razor clam predator observed at the Mar Chiquita coastal lagoon was the American oystercatcher. Two years of observations showed a mean density of 0.34 birds per $1000 \mathrm{~m}^{2}$ $(\mathrm{SD}=0.4)$. Stout razor clams were the most abundant food source in the study area. The birds also feed on intertidal crabs (Cyrtograpsus angulatus and Chasmagnathus granulata) but only during part of the year (Fig. 3). The estimated number of days that oystercatchers preyed on razor clams was $223 \mathrm{~d} \mathrm{yr}^{-1}(\mathrm{SD}=20)$

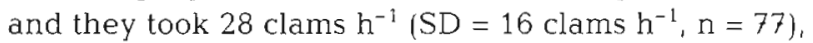
with an average of $3: 43 \mathrm{~h} \mathrm{~d}^{-1}\left(\mathrm{SD}=0: 45 \mathrm{~h} \mathrm{~d}^{-1}, \mathrm{n}=24\right)$ spent feeding on razor clams.

To extract the clam from its burrow, the bird uses its long bill to grasp the clam. In the process some of the razor clams are pulled out of the sediment while in other cases only the soft parts are taken and both valves are left buried standing in life position. Focal sampling showed that out of 300 successful attacks, in 147 cases $(49 \%)$ the shells were left in life position buried in the sediment. The size frequency distribution of buried clams showed slight but significant differences from that of clams left on the surface (Kolmogorov-Smirnov test, $\mathrm{p}=0.015$; Fig. 4A). The difference occurs in the size range of 65 to $90 \mathrm{~mm}$ shell length, which comprised mostly buried shells. However, in most of this size range, both surface and buried shells were represented.

A large proportion $(49 \%, \mathrm{SD}=11 \%, \mathrm{n}=640)$ of the clams preyed upon by oystercatchers are chipped in a distinctive pattern along their posterior margins, with no size selection occurring (Kolmogorov-Smirnov test, $p=0.07$, Fig. 4B). A similar pattern was found in $57 \%$ of the fossil shells ( $\mathrm{SD}=15 \%, \mathrm{n}=320$ ).

Simulation of predation rate: The result of the computer simulation model shows that predation by 1 oystercatcher in the study area could produce 9.2 life-position shells $\mathrm{m}^{-2} \mathrm{yr}^{-1}$ ( $\mathrm{SD}=3.7$ life-position shells $\left.\mathrm{m}^{-2} \mathrm{yr}^{-1}, \mathrm{n}=10000\right)$. Thus, it will take $89.5 \mathrm{yr}(95 \% \mathrm{con}-$ fidence limits: $50-422$ yr) to generate a shell assemblage of a mean density similar to the one found in our study site $\left(824\right.$ clams m$^{-2}, \mathrm{SD}=50$ clams m $\mathrm{m}^{-2} ; 95 \% \mathrm{con}-$ fidence limits $=716-952$ clams $\mathrm{m}^{-2}$ ) if the past conditions were the same as those now.

Discussion. Our results indicate it is likely that timeaveraging (sensu Walker \& Bambach 1971) due to predation generated the Holocene fossil shell assemblages located in coastal Argentina. Oystercatchers (Family Haematopodidae) are distributed world-wide (Hockey 1996) and are well-known predators of siphonate bivalves (e.g. Heppleston 1971). The genus Haematopus is known from the early Pliocene, with individuals that were slightly larger than the modern American oystercatcher H. palliatus (Olson 1985). The living species is 


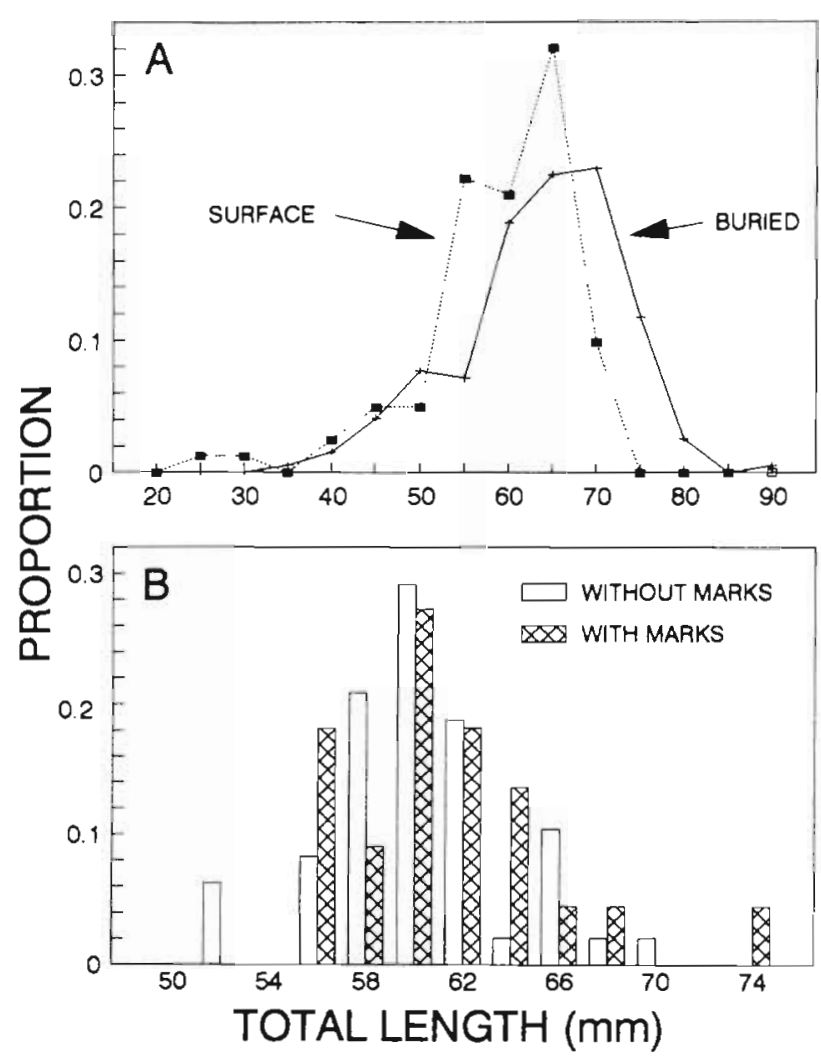

Fig. 4. (A) Size frequency distribution of buried clams compared with that of clams left on the surface after predation by oystercatchers. (B) Size fiequeñcy distribution of cianns preyed by oystercatchers with borders chipped due to predation, and of those preyed upon but without marks

currently distributed between Massachusetts and south central Argentina and found in coastal habitats (Hockey 1996). The American oystercatcher's predation on the stout razor clam has been recorded in the estuaries of the western Atlantic coast (Holland \& Dean 1977b, Bachmann \& Martinez 1995) and our results strongly suggest that their predation contributes to the creation of shell assemblages of the stout razor clam.

American oystercatchers consume an average of 103 clams d $^{-1}$ (Bachmann \& Martinez 1995). This value is, in terms of ash-free dry weight (AFDW), similar to the estimated daily consumption of the Eurasian Oystercatcher Haematopus ostralegus, a species of similar size $(55 \mathrm{~g}$ AFDW in winter and $40 \mathrm{~g}$ AFDW during the rest of the year; Hulscher 1982, Zwarts et al. 1996). Given that mean AFDW of Tagelus plebeius is $0.37 \mathrm{~g}$ ( $S D=0.17 \mathrm{~g}, \mathrm{n}=41$ ) (Bachmann \& Martinez 1995), the demand appears to be very similar to our estimated consumption rate.

Predation marks on clam shells left by birds were reported by Holland \& Dean (1977b) as chips along the posterior margin. Fossil shells (horizons dated $1500 \mathrm{yr}$ BP; Fasano et al. 1982) also showed predation marks on $50 \%$ (Mar Chiquita coastal lagoon) and $87 \%$ (Quequen Grande river; site dated 6440 to 6850 yr BP; Golfieri 1996) of the shells standing in life position. This evidence also suggests that predation was the generating process.

The lack of relationship between burial depth and size of clams that have recently died is similar to that of the fossil clam shell assemblages, a pattern which is different from the usual correlation found between clam size and depth of burial for most siphonate clams (Zwarts \& Wanink 1989). Given that during the process of predation oystercatchers may disrupt the clam sizedepth pattern, the lack of correlation may also be evidence of bird predation.

In the extant population, densities of empty shells standing in life position showing the ligament still attached and flexible were much larger than the density of live individuals, which suggests that they had accumulated over time. Densities reported for extant populations are much lower: up to 300 clams $\mathrm{m}^{-2}$, along the northwestern Atlantic and the Gulf of Mexico estuaries (Chanley \& Castagna 1971), 72 clams m$^{-2}$ in South Carolina (Holland \& Dean 1977b) and up to 120 clams $\mathrm{m}^{-2}$ at the Mar Chiquita lagoon (samples obtained at MLW). Samples taken from the fossil deposits of Mar Chiquita $\left({ }^{14} \mathrm{C}\right.$ date: 1500 yr BP; Schnack et al. 1982) also showed a very large density (up to 1000 clams $\mathrm{m}^{-2}$ ). Similar fossil deposits from Quequen Grande river $\left(38^{\circ} 35^{\prime} \mathrm{S}, 58^{\circ} 41^{\prime} \mathrm{W}\right.$; ${ }^{14} \mathrm{C}$ date: 6440 to 6850 yr BP) also showed extremely high densities $\left(816 \pm 12\right.$ clams $\mathrm{m}^{-2}$; Golfieri 1996). These differences suggest an accumulation of shells over time instead of catastrophic events.

The density distribution of shells along the intertidal also supports the bird predation hypothesis. When the predators are birds, high- and mid-intertidal organisms are more likely to be eaten than those in lower zones (e.g. Heppleston 1971, Hartwick 1976, Frank 1982, Sutherland 1982). Our results showed a dramatically distinct pattern of live individuals and shells standing in life position. While the density of live individuals increases towards the lower intertidal, the density of empty shells standing in life position increases towards the upper intertidal, peaking at the middlehigher intertidal. This difference suggests that the mortality of extant stout razor clams due to oystercatcher predation causes an accumulation of shells in life position at such a rate that, given enough time, a shell bed similar to the Holocene fossil assemblages may be generated. Using current information, the computer simulation showed that oystercatchers may generate a pattern similar to the one found in our study in a relatively short time.

In conclusion, all the evidence suggests that the Holocene shell assemblages from the coastal SW 
Atlantic are the product of time-averaging, and may originate from the oystercatchers' predation on razor clams. Thus, we conclude that these shell assemblages indicate a period of environmental stasis instead of catastrophic or rapid geologic or oceanographic changes.

Acknowledgements. This research was funded by the Universidad Nacional de Mar del Plata (UNMDP) and Fundación Antorchas (\# 13016/1-00012). J.V. was supported by scholarships from Fundación Antorchas and UNMDP, S.B. and L.L. by scholarships from Consejo de Investigaciones Cientificas (Buenos Aires). We thank F. Botto, A. Prieto and 3 anonymous reviewers for useful suggestions that improved the manuscript.

\section{LITERATURE CITED}

Aliotta S, Farinati E (1990) Stratigraphy of Holocene sandshell ridges in the Bahia Blanca Estuary, Argentina. Mar Geol 94:353-360

Altman J (1974) Observational study of behavior: sampling methods. Anim Behav 49:227-265

Bachmann S, Martinez MM (1995) Ecologia alimentaria del Ostrero Pardo (Haematopus palliatus) en la albufera Mar Chiquita. Abstract XVII Reunion Argentina de Ecologia. Mar del Plata, Argentina. Univ Nac Mar del Plata, p 27-28

Carcelles A (1944) Catalogo de los moluscos marinos de Puerto Quequen. Rev Mus La Plata (NS) Zool 3:233-309

Chanley P, Castagna M (1971) Larval development of the stout razor clam. Tagelus plebeius Solander (Solecurtidae: Bivalvia). Chesapeake Sci 12:167-172

Coscaron S (1959) La almeja amarilla de la costa de la Provincia de Buenos Aires. Agro Publ Tec 1:1-66

Dodd JR, Stanton RJ (1990) Paleoecology. Concepts and applications. John Wiley and Sons, New York

Farinati E (1985) Radiocarbon dating of Holocene marine deposits, Bahia Blanca area, Buenos Aires Province, Argentina. In: Rabassa J (ed) Quaternary of South America and Antarctic Peninsula, Vol 3. Balkema, Rotterdam, p $197-206$

Farinati EA, Aliotta S, Ginsberg SS (1992) Mass mortality of a Holocene Tagelus plebeius (Mollusca, Bivalvia) population in the Bahia Blanca estuary, Argentina. Mar Geol 106: $301-308$

Fasano JL, Hernandez MA, Isla FI, Schnack JE (1982) Aspectos evolutivos y ambientales de la laguna Mar Chiquita (provincia de Buenos Aires, Argentina). Oceanol Acta (Suppl A):285-292

Flessa KW, Kowalewski M (1994) Shell survival and timeaveraging in nearshore and shelf environments: estumates from the radiocarbon literature. Lethaia 27:153-165

Frank $P$ (1982) Effects of winter feeding on limpets by black oystercatchers, Haematopus bachmani. Ecology 63: $1352-1362$

Golfien G (1996) Paleoecologia y tafonomia de Tagelus plebeius en sedimentos Holocenos del Rio Quequen Grande (Provincia de Buenos Aires). Tesis de Grado, Fac Cien Exact Nat, Univ Nac Mar del Plata

Editorial responsibility: Otto Kinne (Editor),

Oldendorf/Luhe, Germany
Gonzalez M, Panarello H, Marino H, Valencia S (1983) Niveles marinos del Holoceno en el Estuario de Bahia Blanca (Argentina). Isotopos estables y microfosiles calcarcos como indicadores paleambientales. In: Simp Oscilaciones Niveles del mar durante el ultimo Hemiciclo Deglacial en Argentina. Mar del Plata, Argentina. Univ Nac Mar del Plata, p 48-68

Hartwick EB (1976) Foraging strategy of the black oystercatcher (Haematopus bachmani Auduborn). Can J Zool 54:142-155

Heppleston PB (1971) The feeding ecology of oystercatchers (Haematopus ostralegus L.) in winter in northern Scotland. J Anim Ecol 40:651-672

Hockey PAR (1996) Family Haematopodidae (Oystercatchers). In: del Hoyo J, Elliot A, Sargatal J (eds) Handbook of the birds of the world. Vol 3, Hoatzin to Auk. Lynx Ediciones, Barcelona, p 308-325

Holland A, Dean J (1977a) The biology of the stout razor clam Tagelus plebeius. 1. Animal-sediment relationship, feeding mechanism and community biology. Chesapeake Sc1 18:58-66

Holland A, Dean J (1977b) The biology of the stout razor clam Tagelus plebeius. II. Some aspects of the population dynamics. Chesapeake Sci 18:188-196

Hulscher JB (1982) The oystercatcher Haematopus ostralegus as a predator of the bivalve Macoma balthica in the Dutch Wadden Sea. Ardea 70:89-152

Isla F, Rivero D'Andrea I (1.993) Procesos retrotafonomicos en secuencias de aguas someras. Pesquisas 20:90-95

Kidwell SM, Jablonski D (1983) Taphonomic feedback: ecological consequences of shell accumulation. In: Tevesz MJS, MCCall PL (eds) Biotic interactions in recent and fossil benthic communities. Plenum Press, New York, p $195-248$

Manly B (1992) The design and analysis of research studies. Cambridge University Press, Cambridge

Olson SL (1985) The fossil record of birds. In: Farner DS, King JR, Parker KC (eds) Avian Biology, Vol 8. Academic Press, New York, p 79-238

Thompson SK (1992) Sampling. John Wiley \& Sons, Inc, New York

Schnack EJ, Fasano JL, Isla FI (1982) The evolution of Mar Chiquita lagoon, Province of Buenos Aires, Argentina. In: Colquhoun DJ (ed) Holocene sea-level fluctuations: magnitudes and causes. IGCP 61, Univ South Carolina, Columbia, p 143-155

Sutherland WJ (1982) Spatial variation in the predation of cockles by oystercatchers at Traeth Meylong. Anglesey. II. The pattern of mortality. J Anim Ecol 51:491-500

Walker KR, Bambach RK (1971) The significance of fossil assemblages from fine-grained sediments: time-averaged communities. Geol Soc Am Abstr Programs 3:783-784

Zar JH (1984) Biostatistical analysis. Prentice-Hall, Englewood Cliffs, $\mathrm{NJ}$

Zwarts L, Cayford JT, Hulscher JB, Kersten M, Meire PM, Triplet $P(1996)$. Prey size selection and intake rate. In: Goss Custard JD (ed) The oystercatcher. From individuals to populations. Oxford University Press. Oxford, p 30-55

Zwarts L, Wanink J (1989) Siphon size and burying depth in deposit-and suspesion-feeding benthic bivalves. Mar Biol 100:227-240

Submitted: December 16, 1997; Accepted: April 7, 1998

Proofs received from author(s): June 2, 1998 